\title{
Efficacy of a Natural Papain-Induced Enzyme on Virgin Coconut Oil-Based Hand and Body Lotions with Added Orange Peel Extract
}

\author{
Indah Yuniarti ${ }^{*}$, Enrico Fendy Sapatra ${ }^{1}$, Sagitha Fitri Novia ${ }^{1}$, Hovivah $^{1}$, Vita Paramita ${ }^{1}$, \\ Mohamad Endy Yulianto ${ }^{1}$
}

${ }^{1}$ Chemical Industrial Engineering Technology, Diponegoro University, Semarang 50275, Indonesia

\begin{abstract}
The objective of this research was to determine the effect of addition of natural papain enzyme on virgin coconut oil production and to characterise the physical quality of hand and body lotions made with virgin coconut oil. A natural papain enzyme was extracted to separate the virgin coconut oil from blondo and water, and the virgin coconut oil was then made into a hand and body lotion. The highest yield of virgin coconut oil $(13.8 \pm 5.30 \%)$ was obtained with a $45 \%$ papain enzyme extract. The virgin coconut oil had an acid number of $0.135 \pm 0.50 \%$, which fulfilled the SNI 7381:2008 standard for acid numbers. The peroxide number for the virgin coconut oil was $1.16 \pm 0.51 \mathrm{meq} / \mathrm{kg}$ and in accordance with the SNI 7382:2008 standard for peroxide numbers. The organoleptic test for hand and body lotion products prepared from the virgin coconut oil extracted with the papain enzyme was carried out with 32 respondents. The lotion colour had adequate acceptance by the respondents, who also viewed the lotion texture, homogeneity and humidity as satisfactory.
\end{abstract}

Keywords: Body lotion; Vegetable oil; Virgin coconut oil

\section{Introduction}

For the past two decades, coconut (Cocos nucifera L.) fruit has gained popularity due to the stability and benefits of the saturated fatty acids in its triglycerides (Satheeshan et al., 2020). In Indonesia, coconut fruit is typically used in cooking for its good flavour. However, the value of coconut fruit can be increased by processing it to produce coconut oil. According to Harimurti et al. (2020), two types of coconut oil can be obtained: ordinary coconut oil and virgin coconut oil (VCO). Both types have many benefits; for example, ordinary coconut oil can be processed for use as an alternative fuel to replace petroleum diesel fuel (Muharam and Putri, 2018), while VCO can be used to maintain skin smoothness and moisture because of its lauric acid content (Harimurti et al., 2020).

VCO is easy to produce using simple methods. Enzymatic methods are particularly advantageous because enzymes are nontoxic accelerating agents and are active at low concentrations. Enzymes are also produced from natural materials, so they are environmentally friendly (Harimurti et al., 2020). One enzyme that can be used to produce VCO is papain, a proteolytic sulphydryl protease enzyme found in the fruit sap, stems and leaves of the papaya plant (Carica papaya L.). The papain enzyme is easy to obtain at anaffordable price (Setiadi and Hidayah, 2018). In VCO production, papain can help break 
the lipoprotein bonds in coconut milk emulsions to release the oil for collection (Silaban et al., 2014). Papain is therefore a useful active ingredient for producing skin cleansing creams, especially for the face and for dissolving dead cells that are difficult to physically detach from the human skin (Soda and Agustini, 2013). VCO can soften and moisturise the skin, so it can be used as the base material for producing skin lotions. The benefits of hand and body lotions can be further improved by adding an antioxidant agent to slow down the production of wrinkles and stop premature aging (Park et al., 2014). Orange peel is a good antioxidant with more activity than the flesh of the orange fruit (Hegazy and Ibrahium, 2012).

The present research focuses on the novel application of a natural papain extract from papaya leaves for VCO production. The papain extract was prepared using a maceration method. Specifically, the effects of the addition of a natural papain extract were examined on the yield, free fatty acid content and peroxide number of the resulting VCO. In addition, the effect of adding an orange peel extract on the $\mathrm{pH}$, density and viscosity of a VCO body lotion was determined.

\section{Methods}

\subsection{Materials}

The materials included mature coconuts, tempe yeast and orange peel obtained from a suburban area in Semarang (Indonesia). A commercial extra virgin coconut oil product was purchased from CV Ajisaka Kelapa (Malang, Indonesia). Acetic acid-chloroform solution, Phenol Pthalein (PP) indicator, and buffer solution (pH 4.01 and 7.01) were purchased from Merck (Darmstadt, Germany). Potassium iodide, $0.1 \mathrm{~N} \mathrm{Na}_{2} \mathrm{~S}_{2} \mathrm{O}_{3}, 0.1 \mathrm{~N} \mathrm{KOH}$, distilled water and $96 \%$ alcohol were purchased from CV Indrasari (Semarang, Indonesia).

\subsection{Coconut Cream Preparation}

A $1000 \mathrm{~g}$ sample of mature coconut meat was peeled, shredded and added to warm water at a ratio of 1:1, followed by filtration through a filter cloth to obtain the coconut milk. A $1000 \mathrm{~mL}$ sample of coconut milk was then allowed to stand at room temperature until it separated into 2 layers: a skim layer (bottom layer) and the coconut cream. The skim layer was removed, leaving $800 \mathrm{~mL}$ coconut cream. A $600 \mathrm{~mL}$ sample of the coconut cream was then used to make VCO with enzymatic papain and the remaining $200 \mathrm{~mL}$ was fermented with tempe yeast by mixing $3 \mathrm{~g}$ of tempe yeast in $5 \mathrm{~mL}$ distilled water (Sapatra et al., 2019).

\subsection{Preparation of the Papain Extract from Papaya Leaves}

Young papaya leaves ( $25 \mathrm{~g}$ ) were removed from a papaya tree, washed and chopped (Ihromilala, 2016). Distilled water was added at a 1:1 ratio to the mass of papaya leaves and the leaves were blended in a blender. The blended papaya leaves were left at room temperature for $24 \mathrm{~h}$, with occasional stirring, to extract the papain protein. The papaya leaf residue was then removed by filtering the extract through a filter cloth (150 mesh).

\subsection{Coconut Oil Preparation}

Figure 1 shows the coconut oil production protocol based on papaya leaf papain treatment and on tempe yeast treatment. The prepared papain enzyme extract was added to $200 \mathrm{~mL}$ of coconut cream with varying ratios of enzyme to cream (15, 30 and $45 \%)$. The tempe yeast-based coconut oil was prepared by adding $0.6 \mathrm{~g}(\mathrm{w} / \mathrm{v})$ of tempe yeast to 200 $\mathrm{mL}$ of coconut cream. The mixtures were then left for $24 \mathrm{~h}$ to allow formation of 3 layers: pure coconut oil (upper layer), blondo (middle layer) and water. The pure coconut oil (VCO) was separated with a separatory funnel (Sapatra et al., 2019). 


\subsection{Orange Peel Extract Preparation}

A $25 \mathrm{~g}$ sample of orange peel was dried and ground until smooth and then dissolved in $10 \mathrm{~mL}$ ethanol. The mixture was filtered through a filter cloth (150 mesh) to obtain the orange peel extract.

\subsection{Preparation of the Hand and Body Lotion}

The lotion was prepared from $5 \mathrm{~g}$ cocoa butter, $30 \mathrm{~g}$ beeswax and $50 \mathrm{~mL} \mathrm{VCO}$, which were mixed and heated at $50^{\circ} \mathrm{C}$ and then stirred until homogeneous. The orange peel extract was added to the mixture at a ratio of 3, 5, and 7\%. A $3 \mathrm{~mL}$ volume of polysorbate 20 was added as an emulsifier, $0.2 \mathrm{~mL}$ methyl paraben was added as a preservative and 5 drops of perfume were added as a fragrance (Figure 1).

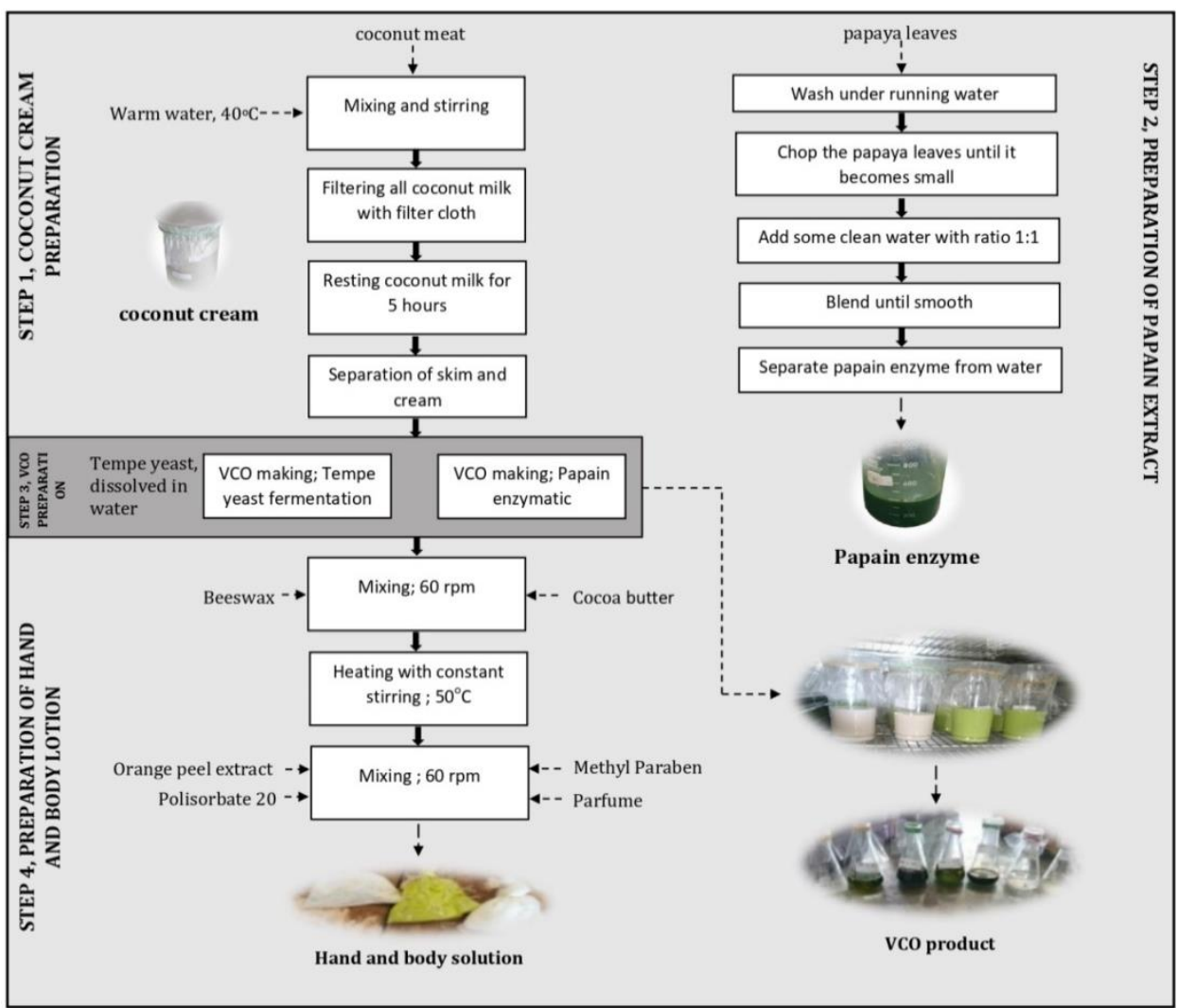

Figure 1 Schematic process showing the preparation of a natural papain enzyme extract from papaya leaves and its use in the production of virgin coconut oil hand and body lotion with added orange peel extract

\subsection{Determination of the Coconut Oil Yield}

The oil yield was determined from the ratio of the weight of the oil produced and the initial raw material weight (Equation 1).

$$
\text { Yield }=\frac{\text { Final weight }}{\text { Initial weight }} \times 100 \%
$$

\subsection{Determination of Peroxide Numbers}

A $2.5 \mathrm{~g}$ sample of VCO was placed in an Erlenmeyer flask, followed by the addition of $15 \mathrm{~mL}$ acetic acid-chloroform $(3: 2, \mathrm{v} / \mathrm{v})$ and $0.25 \mathrm{~mL}$ saturated KI solution. The flask was sealed and the mixture was shaken several times for $1 \mathrm{~min}$, and then $15 \mathrm{~mL}$ distilled water was added. The mixture was then titrated with $0.1 \mathrm{~N} \mathrm{Na}_{2} \mathrm{~S}_{2} \mathrm{O}_{3}$ until a yellow colour formed. A $0.25 \mathrm{~mL}$ volume of $1 \%$ starch solution was then added and the mixture was titrated again 
until the colour turned blue. The peroxide value was expressed in milliequivalents of peroxide per $1000 \mathrm{~g}$ of sample (Equation 2).

$$
\text { Peroxide number }=\frac{m L \mathrm{Na}_{2} \mathrm{~S}_{2} \mathrm{O}_{3} \times 0.1 \mathrm{~N} \times 1000}{\text { sample weight }}
$$

\subsection{Determination of Acid Numbers}

A $4 \mathrm{~g}$ sample of VCO was placed in an Erlenmeyer flask, followed by addition of $10 \mathrm{~mL}$ 96\% alcohol and PP indicator. The mixture was then titrated with a standardised $0.1 \mathrm{~N}$ $\mathrm{NaOH}$ solution until a red colour appeared. The percentage of free fatty acids was determined using Equation 3. This value is expressed as oleic acid equivalents for most oils and fats, but coconut oil and palm kernel oil are expressed as lauric acid equivalents and palm oil is expressed as palmitic acid equivalents. The free fatty acids are expressed as \% FFA or as an acid number.

$$
\% F F A=\frac{m L N a O H \times 0.1 N \times \text { Fatty acid molecular weight } \times 100 \%}{\text { Sample weight } \times 1000}
$$

\subsection{Organoleptic Test of the VCO}

The organoleptic test was carried out using the scoring test, where a higher number indicated better VCO quality. The VCO samples were evaluated by asking the panellists to score how they liked the taste, colour and aroma of each product. The number of samples was determined by Slovin's method and expressed in Equation 4 (Ansar et al., 2017):

$$
n=\frac{N}{1+n e^{2}}
$$

where $N$ is the population (a student classroom of 48 members), $n$ is the number of samples and $e$ is error tolerance $(0.01)$.

\subsection{Hand and Body Lotion Test}

\subsection{1. $\mathrm{pH}$ testing}

Samples (1 g) of lotion containing 3, 5 or 7\% orange peel extract were dissolved in 100 $\mathrm{mL}$ of distilled water and the $\mathrm{pH}$ was determined using a standard $\mathrm{pH}$ electrode (Hanna Digital pH Meter HI 98107, SG, Singapore).

\subsubsection{Organoleptic test}

The organoleptic test was carried out as a scoring test, where a high number indicated better quality. The panellists were asked to score how they liked the taste, colour and aroma of the product. The number of samples was determined by Slovin's Equation (Ansar et al., 2017).

\section{Results and Discussion}

\subsection{Chemical Analysis of the VCO}

The results for the VCO prepared using tempe yeast or by the papain enzyme extract were compared with a commercially available market VCO in terms of \%yield, \%FFA content, and peroxide number (Table 1 ).

Table 1 presents the chemical content of VCO with the yield calculated by comparing the oil produced with the initial coconut milk volume and expressed as a percentage. The VCO produced with 45\% papain enzyme extract had the highest yield (13.8\%).

The breakdown of the emulsion in coconut milk can be assisted by proteolytic enzymes, such as papain, which can catalyse protein breakdown reactions by hydrolysing peptide bonds and forming simple compounds (Sapatra et al., 2019). 
Table 1 Chemical content of virgin coconut oil

\begin{tabular}{ccccc}
\hline Sample & De-emulsifier (\%) & Yield (\%) & FFA (\%) & Peroxide Number (meq/kg) \\
\hline Extract of Papain Enzyme & & & \\
P1 & 15 & $12.0 \pm 5.66$ & $0.195 \pm 0.01$ & $2.44 \pm 0.57$ \\
P2 & 30 & $12.5 \pm 6.36$ & $0.188 \pm 0.02$ & $1.78 \pm 0.26$ \\
P3 & 45 & $13.8 \pm 5.30$ & $0.135 \pm 0.50$ & $1.16 \pm 0.51$ \\
\hline Tempe Yeast & & & & \\
P4 & 1.5 & $10.8 \pm 1.06$ & $0.215 \pm 0.28$ & $1.80 \pm 0.28$ \\
\hline Market Purchase & & & & \\
\hline P5 & - & - & $0.198 \pm 0.00$ & $5.80 \pm 0.85$ \\
\hline
\end{tabular}

One technique for extraction of papain enzyme is maceration, which is carried out by soaking a simplicia powder in a filtered liquid. The liquid penetrates the cell wall and enters the cell compartment that contains the desired active substance. The active substance dissolves because of the difference in concentration of the active substance inside and outside the cell, so the concentrated solution is forced out (Sudarwati and Fernanda, 2019).

The formation of virgin coconut oil by papain treatment is due to the hydrolysis of the peptide bonds in the coconut cream. The hydrolysis process causes destabilisation of the emulsion system in the coconut milk, resulting in the release of the oil as virgin coconut oil (Setiadi and Hidayah, 2018). This causes a faster formation and increased yield of VCO. The low yield obtained in the present study probably reflects the use of an unpurified, naturally extracted papain enzyme from the papaya leaf. Paramita et al. focused their studies on noncommercial enzymes in order to avoid the expense of mass-scale production (Naidu et al., 2012; Paramita and Yulianto, 2019; Paramita et al. 2019). However, Qiuyu et al., 2009 applied $0.075 \%$ papain and obtained an $82.9 \%$ yield of VCO. The use of a low temperature for VCO production $\left(27^{\circ} \mathrm{C}\right)$ using papain also makes this a green process and environmentally friendly (Muharam and Putri, 2018; Mulia et al., 2018). By contrast, the VCO production using tempe yeast fermentation gave the lowest yield due to the influence of temperature on Rhizopus oligosporus enzyme activity. The optimum temperature for growth of this fungus is $30-35^{\circ} \mathrm{C}$ (Salehoddin et al., 2020).

The FFA content is important in the final VCO product due to the effects on the taste and smell of the oil. A high water content in VCO promotes the activity of microorganisms that can give rise to oil with a high level of fatty acids and further reduce its quality (Iskandar et al., 2015). The FFA values were calculated based on the colour change from yellow to purplish-pink while titrating the VCO with NaOH. As shown in Table 1, treatment with the papain enzyme resulted in lower FFA values compared to the other samples. The lowest value of $0.135 \pm 0.50 \%$ was obtained for P3, which was found to have fulfilled the $0.2 \%$ maximum acid value required by SNI 7381:2008 for coconut oil and the value decreased as the enzyme concentration increased. The market VCO had a FFA value of $0.195 \pm 0.01 \%$, while the tempe yeast fermentation product had a value of $0.215 \pm 0.28 \%$ and these values, according to Male et al. (2014), were unacceptable according to the current standard (BSN, 2008). The high FFA level was associated with the high water content in the VCO, which affects its quality, while the high acid numbers were derived from oil hydrolysis or poor processing.

Peroxide numbers are very important indicators of damage to the oil due to the binding of oxygen to the double bonds of unsaturated fatty acids. A higher peroxide number indicates a greater risk of rancidity and the oil, when used in foods, can later cause fat deposition in blood vessels and decrease the digestibility after consumption (Talbot, 2016). 
The P3 sample also had the lowest amount of peroxide, at $1.16 \pm 0.51 \mathrm{meq} / \mathrm{kg}$, and this also met the maximum level of $2.0 \mathrm{meq} / \mathrm{kg}$ required by the SNI 7382:2008 standard for coconut oil. By contrast, P1 did not meet the required standard, as its value was $2.44 \pm 0.57$ $\mathrm{meq} / \mathrm{kg}$ due to oxidation and contact with air during titration. The peroxide number tended to decrease at higher enzyme concentrations due to the higher frequency of attachment of the enzyme to the substrate, the ease of interaction of the enzyme molecules with other molecules and the enhanced ability to protect the oil from direct contact with air. The papain enzyme has high proteolytic power and an ability to reduce direct interactions with oxygen, and it can degrade protein components and break down the cell walls of the tissues that contain the coconut milk to separate the oil from water. This results in less water in the oil and reduces oxidation processes and the peroxide number.

The value for fermentation was also in accordance with the SNI requirements, whereas the commercial market VCO value, at $5.80 \pm 0.85 \mathrm{meq} / \mathrm{kg}$, was not. This meant that the market VCO was already exhibiting signs of rancidity caused by the formation of peroxides in the double bonds of several unsaturated fatty acids. The high peroxide number indicated a lower oil quality (Talbot, 2016).

\subsection{Physical Analysis of the VCO}

The results for VCO prepared with tempe yeast and papain enzyme and for the market VCO being for physical characteristics, such as colour, texture and aroma, based on organoleptic test results from 32 respondents are shown in Figure 2.

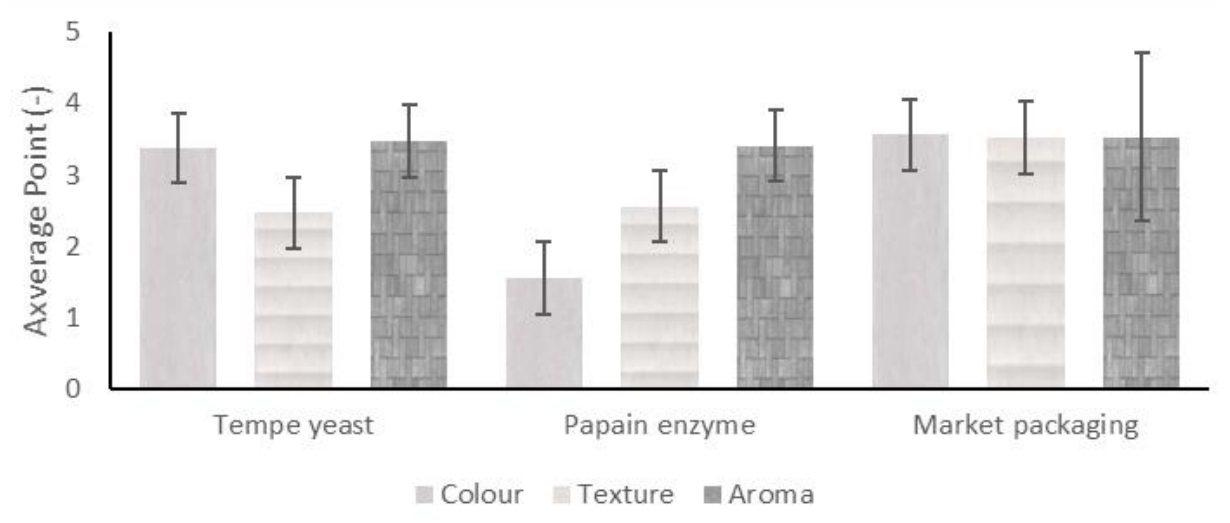

Figure 2 Physical analysis of VCO prepared with tempe yeast and papain enzyme or purchased from a commercial market in terms of colour, texture and aroma

Figure 2 shows the scoring method ranging from 1 to 4 used in the organoleptic tests to assess the product. A higher number indicates better quality. The colour was determined as 1 = very turbid, $2=$ turbid, $3=$ clear, 4 = very clear, while the texture was evaluated as 1 = very runny, $2=$ runny, $3=$ thick, $4=$ very thick and the aroma was classified as $1=$ very strong rancid aroma, 2 = rancid aroma, $3=$ good aroma, $4=$ very good aroma. The product samples tested included the VCO produced with tempe yeast (A), VCO produced with papain enzyme (B) or commercial VCO purchased from a market (C). The VCO produced with tempe yeast had a clear colour with a slightly runny texture, the product produced with papain enzyme had a cloudy colour with a slightly runny texture, and the commercial product had a clear colour with a thick texture. None of the VCO products had a rancid aroma.

The watery texture observed in the oil produced with tempe yeast and papain enzyme was caused by the imperfect separation process between the oil and water using a separatory funnel, while the murky colour observed with the papain enzyme was due to the 
yellowish-green oil-soluble pigments (chlorophyll and carotene) contained in the papaya leaf (Soleha et al., 2018).

\subsection{Chemical Analysis of the Hand and Body Lotion}

The results for the hand and body lotion prepared with $45 \%$ papain enzyme and addition of 3, 5 and $7 \%$ orange peel extract, the lotion prepared with tempe yeast VCO, and the lotion prepared with market purchased VCO were analysed for their $\mathrm{pH}$, density and viscosity, as shown in Table 2 . The best $\mathrm{pH}$, with a value close to neutral, was recorded for $\mathrm{P} 2$, which is the papain enzyme VCO lotion $+5 \%$ orange peel extract. The average $\mathrm{pH}$ value for all the samples ranged between $5.65 \pm 0.35$ and $6.70 \pm 0.28$, and values in this range are considered to be within the allowable limits ( $\mathrm{pH} 4.5$ to 8) according to SNI 16-4399-1996 for skin moisturisers. The best $\mathrm{pH}$ for the skin varies between $\mathrm{pH} 4$ and 7 , indicating that all the samples tested here were safe to use as a moisturising lotions. Sumbayak and Diana, (2018) found that lotions with lower pH caused dry skin and irritation by damaging the skin epidermis.

Table 2 Chemical characteristics of hand and body lotion

\begin{tabular}{|c|c|c|c|c|}
\hline Sample & $\begin{array}{l}\text { Orange peel } \\
\text { extract }(\%)\end{array}$ & $\begin{array}{l}\mathrm{pH} \\
(-) \\
\end{array}$ & $\begin{array}{c}\text { Density } \\
\left(\mathrm{gr} / \mathrm{cm}^{3}\right)\end{array}$ & $\begin{array}{l}\text { Viscosity } \\
(\mathrm{mPa} \cdot \mathrm{s}) \\
\end{array}$ \\
\hline \multicolumn{5}{|c|}{ Papain enzymatic $45 \%$ of VCO production with } \\
\hline P1 & 3 & $5.65 \pm 0.35$ & $1.020 \pm 0.026$ & $479.9681 \pm 1.672$ \\
\hline $\mathrm{P} 2$ & 5 & $6.70 \pm 0.28$ & $0.982 \pm 0.023$ & $427.917 \pm 20.685$ \\
\hline P3 & 7 & $5.90 \pm 0.14$ & $0.962 \pm 0.091$ & $355.3996 \pm 66.856$ \\
\hline \multicolumn{5}{|c|}{ Tempe yeast fermentation } \\
\hline P4 & - & $6.25 \pm 0.07$ & $0.993 \pm 0.007$ & $452.0624 \pm 64.932$ \\
\hline \multicolumn{5}{|c|}{ Market Package } \\
\hline P5 & - & $5.75 \pm 0.21$ & $1.005 \pm 0.046$ & $465.7556 \pm 56.806$ \\
\hline
\end{tabular}

The density was measured to determine the stability of the emulsion products, as an inappropriate ratio between the dispersing and dispersed phase usually reduces the stability (Kurniawan, 2012). The average density was lower for the samples with orange peel extract than without orange peel extract, and this lower density is associated with the increase in the volume of the lotion due to the added extracts (Tumbelaka et al., 2019). The values ranged from $0.962 \pm 0.091$ to $1.020 \pm 0.026 \mathrm{gr} / \mathrm{cm}^{3}$ and these were within the $0.95-$ $1.05 \mathrm{gr} / \mathrm{cm}^{3}$ required by standard SNI 16-4399-1996.

The average viscosity was also lower for the samples with orange peel extract than for the others, and the value decreased as the concentration of papaya leaf extract increased. The viscosity also affected the density, so a higher value caused a greater density of the product (Tumbelaka et al., 2019).

\subsection{Physical Characteristics of the Hand and Body Lotion}

The hand and body lotion prepared with 3, 5 and 7\% orange peel extract was compared with the market VCO for the physical characteristics of colour, texture, homogeneity and moisture (Figure 3).

The results did not differ appreciably for the different samples. For example, sample (A) was yellow and (B) was yellowish-green, while (C) was also yellow; however, they were all thick textured, homogenous and very humid. The different colour recorded in sample (B) was caused by the addition of papaya leaf extract that contained yellowish-green pigments (chlorophyll and carotene), which are soluble in oil (Soleha et al., 2018). 


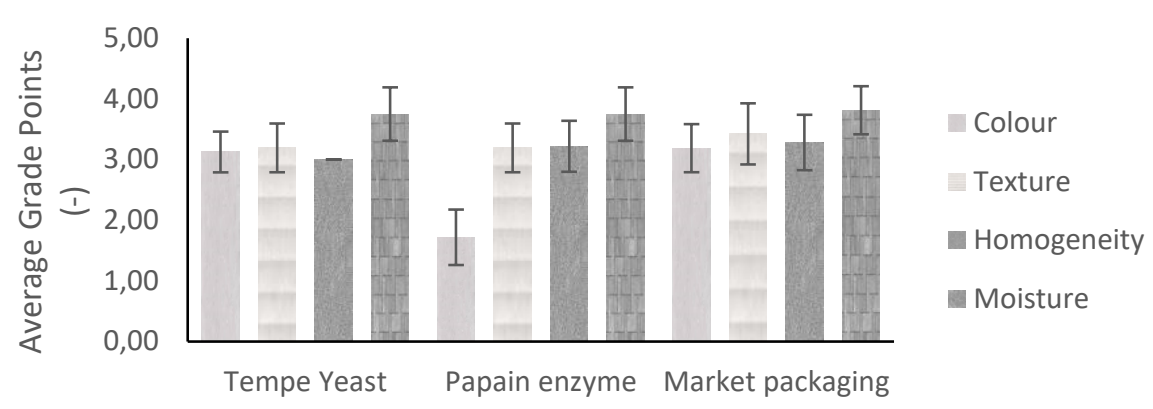

Figure 3 The physical analysis of hand and body lotion by organoleptic testing in terms of colour, texture, homogeneity and moisture

The organoleptic tests for hand and body lotion products prepared from papain enzyme-treated VCO carried out with 32 respondents confirmed that the texture, homogeneity and moisture were acceptable. As shown in Figure 3, the texture, homogeneity and moisture scores were 3.19, 3.22 and 3.75, respectively, based on a maximum score of 5 for each characteristic, whereas the score for colour was 1.7, indicating adequate acceptance.

Rini et al. focused their study on skin lotion from VCO containing black tea extract as a skin protector and natural dye. They showed organoleptic test scores of 4.0 for colour, 4.3 for odour, 4.5 for appearance, and 4.5 for adhesiveness. Black tea extract contains polyphenol compounds, which have antioxidant activity and have attractive colours, making tea suitable as a natural dye for cosmetic ingredients (Rini et al., 2020).

Skin contamination is one of the likeliest risks with potential health consequences for people with occupational exposure to various hazards. Many of the skin care products that are available on the market are based on chemical formulations that are harsh, irritating and even toxic. This underlines the need to identify and develop a research protocol for natural products. In this context, the topical body lotion formulation developed in this study is significant for its potential to reduce the danger to human health, while also lessening pollution in the environment. The VCO, which constitutes a major proportion of the formulation, itself acts as a preservative, thereby increasing the shelf life of body lotion and protecting it from microbial degradation. The body lotion developed in the present study is free from skin irritancy, has a long shelf life and is quite stable and safe (Satheeshan et al., 2020).

\section{Conclusions}

The highest yield of VCO, at $13.8 \pm 5.30 \%$, was obtained using a $45 \%$ papain enzyme extract. The resulting VCO had an acid number of $0.135 \pm 0.50 \%$, which fulfilled the SNI $7381: 2008$ standard for acid numbers, and a peroxide number of $1.16 \pm 0.51 \mathrm{meq} / \mathrm{kg}$, which was also in accordance with the SNI 7382:2008 standard for peroxide numbers. Organoleptic tests conducted by 32 respondents on the hand and body lotion products made from VCO prepared using the papain enzyme extract showed that the colour had an adequate acceptance, while the texture, homogeneity and humidity were viewed as satisfactory. Further studies should focus on the isolation process for papain.

\section{Acknowledgements}

This scientific research was partly supported by the Ministry of Higher Education, Indonesia [No. 176-23/UN7.5.1/PG/2016]. 


\section{References}

Ansar, A., Lukum, A., Arifin, A., Dengo, Y.J., 2017. The Influence of School Culture on the Performance of High School English Teachers in Gorontalo Province. International Journal of Education and Research, Volume 5(10), pp. 35-48

Harimurti, S., Rumagesan, R.M., Susanawati, 2020. Environmentally Friendly Production Method of Virgin Coconut Oil using Enzymatic Reaction. In: IOP Conference Series: Materials Science and Engineering, International Conference on Engineering, Technologies, and Applied Sciences (ICETsAS), 17-18 October 2019, Bengkulu, Indonesia, Volume 874(1), pp. 1-7

Hegazy, A.E., Ibrahium, M.I., 2012. Antioxidant Activities of Orange Peel Extracts. World Applied Sciences Journal, Volume 18(5), pp. 684-688

Ihromilala, H., 2016. The Effect of Crude Papain Enzyme Extract Concentration from Papaya Leaves and Ripening Time to Coconut Oil Yield. Undergraduate Thesis, Undergraduate Program, Universitas Islam Negeri, Malang, Indonesia

Iskandar, A., Ersan, E., Edison, R., 2015. Pengaruh Dosis Enzim Papain terhadap Rendemen dan Kualitas Virgin Coconut Oil (VCO) (The Effect of Papain Enzyme Rate on the Yield and Quality of Virgin Coconut Oil (VCO)). Jurnal Argo Industri Perkebunan Uournal of Plantation Agroindustry), Volume 3(2), pp. 82-93

Kurniawan, R., 2012. Pembuatan body lotion dengan menggunakan ekstrak daun handeuleum (grapthopyllum pictum (LINN) GRIFF) sebagai emolient. (Making Body Lotion using Handeuleum Leaf Extract (Graptophyllum pictum (Linn) Griff) as an Emolient). Master's Thesis, Graduate Program, Universitas Indonesia, Jakarta, Indonesia

Male, K., Nuryanti, S., Rahmawati, S., 2014. Ekstrak Enzim Protease dari Daun Palado (Agave angustifolia) dan Pemanfaatannya dalam Proses Pembuatan Virgin Coconut Oil (The Extract of Protease Enzyme of Palado (Agave angustifolia) Leaf and Its Use in the Making Process of Virgin Coconut Oil). Jurnal Akademika Kimia (Journal of Chemical Academic), Volume 3(3), pp. 111-120

Muharam, Y., Putri, A.D., 2018. Simulation of Hydrotreating of Vegetable Oil in a Slurry Bubble Column Reactor for Green Diesel Production. International Journal of Technology, Volume 9(6), pp. 1168-1177

Mulia, K., Adam, D., Zahrina, I., Krisanti, E., 2018. Green Extraction of Palmitic Acid from Palm Oil using Betaine-Based Natural Deep Eutectic Solvents. International Journal of Technology, Volume 9(2), pp. 335-344

Naidu, M.M., Kumar, P.V.S., Shyamala, B.N, Sulohanamma, G., Prakash, M., Thakur, M.S., 2012. Enzyme-Assisted Process for Production of Superior Quality Vanilla Extracts from Green Vanilla Pods using Tea Leaf Enzymes. Food and Bioprocess Technology, Volume 5(2), pp. 527-532

Paramita, V., Yulianto, M.E., 2019. Response Surface Analysis on the Microwave IntegratedRumen Based Extraction of Natural Vanillin from Cured Vanilla Pods. Journal of Physics: Conference Series, Volume 1295(1), pp. 1-10

Paramita, V., Yulianto, M.E., Hartati, I., 2019. Kinetic Modelling and Activation Energy on Microwave Integrated Enzymatic Leaching of Vanillin from Dried Vanilla Pods. Rasayan Journal of Chemistry, Volume 12(2), pp. 484-493

Park, J.H., Lee, M., Park, E., 2014. Antioxidant Activity of Orange Flesh and Peel Extracted with Various Solvents. Preventive Nutrition and Food Science, Volume 19(4), pp. 291298

Qiuyu, X., Rui, L., Meiqiu, L., Hua, C., Songlin, Z., 2009. Extraction of Virgin Coconut Oil by Papain. Chinese Journal of Tropical Crops, Volume 30(3), pp. 386-391 
Rini, Anggraini, T., Ritonga, N.B., 2020. Making Skin Lotion from Virgin Coconut Oil with Adding Several Natural Plants Extract as a Skin Protector. In: IOP Conference Series: Earth and Environmental Science, International Conference of Sustainability Agriculture and Biosystem 12-13 November 2019, West Sumatera Province, Indonesia, Volume 515(1), pp. 1-6

Salehoddin, M.R., Hafizh, N., Utami, T.S., Arbianti, R., Hermansyah, H., 2020. Effect of Temperature Shift Strategy in the Production Unsaturated Fatty Acids from Rhizopus oligosporus. AIP Conference Proceedings, Volume 1155(1), pp. 1-5

Sapatra, E.F., Yuniarti, I. Imamsyah, R.A.S., 2019. An Effort to Increase the Potential of Virgin Coconut Oil with Pendawa Technique. In: IOP Conference Series: Materials Science and Engineering, Annual Conference on Industrial and System Engineering (ACISE), 23-24 April 2019, Semarang, Central Java, Indonesia, Volume 598(1), pp. 1-6

Satheeshan, K.N., Seema, B.R., Manjusha, A.V.M., 2020. Development of Virgin Coconut Oil Based Body Lotion, Volume 9(5), pp. 96-101

Setiadi, S., Hidayah, N., 2018. The Effect of Papain Enzyme Dosage on the Modification of Egg-yolk Lecithin Emulsifier Product through Enzymatic Hydrolysis Reaction. International Journal of Technology, Volume 9(2), pp. 380-389

Silaban, R., Manullang, R.S., Hutapea, V., 2014. The Making of Virgin Coconut Oil with Combination Method from Fermentation and Enzymatic using Pineapple Extracts. Chemistry Journal, Volume 6(1), pp. 56-64

Soda, F.N., Agustini, R., 2013. Pengaruh Penambahan Ion Logam $\mathrm{K}^{+}$Terhadap Aktivitas Enzim Papain (The Addition Effect of the Metal Ion $\mathrm{K}^{+}$on the Papain Enzyme Activities). Unesa Journal of Chemistry, Volume 2(2), pp. 29-34

Soleha, M., Maligan, J.M., Yunianta, Y., 2018. Pengaruh Penambahan Enzim Papain Terhadap Karakteristik Fisik, Kimia, dan Organoleptik Susu Kedelai (Kajian Jenis Kedelai dan Konsentrasi Enzim Papain) (The Effect of Papain Enzyme Addition on the Physical, Chemical, and Organoleptic Characteristic of Soy Milk (Study of Soybean Type and Enzyme Papain Concentration)). Jurnal Pangan dan Agroindustri (Food and Agroindustry Journal), Volume 6(3), pp. 18-29

Sudarwati, T.P.L., Fernanda, H.F., 2019. The Application of the Use of Papaya Leaves (Carica papaya) as a Larvicide to Larvae of Aedes aegypti. Indonesia: Graniti

Sumbayak, A.R., Diana, V.E., 2018. Formulasi Hand Body Lotion Ekstrak Etanol Kulit Buah Semangka (Citrillus vulgaris) (Hand Body Lotion Formulation of Watermelon (Citrillus vulgaris Schard) Ethanol Extract). Jurnal Dunia Farmasi (Journal of The Pharmaceutical World), Volume 2(2), pp. 70-76

Talbot, G., 2016. The Stability and Shelf Life of Fats and Oils. Food and Beverage Stability and Shelf Life, Woodhead Publishing Series in Food Science, Technology and Nutrition, pp. 461-503

Tumbelaka, R.M.M.Y., Momuat, L.I., Wuntu, A.D., 2019. Pemanfaatan VCO Mengandung Karotenoid Tomat dan Karagenan dalam Pembuatan Lotion (Utilization of VCO Containing Tomato Carotenoid and Carefulness in Making a Lotion). Jurnal Ilmiah Farmasi (Pharmaceutical Scientific Journal), Volume 8(1), pp. 94-105 